\title{
Amyloid Beta 1-40 Measurement
}

National Cancer Institute

\section{Source}

National Cancer Institute. Amyloid Beta 1-40 Measurement. NCI Thesaurus. Code

C103353.

The determination of the amount of amyloid beta protein which is composed of peptides 1 to 40 in a sample. 